\title{
HUBUNGAN ANTARA KECERDASAN EMOSIONAL DENGAN PRESTASI BELAJAR PADA SISWA KELAS VIII DI SMP NEGERI I GRATI
}

\author{
Ch. Erghiezha Ninuk Indrati K. \\ Prisca Aini Sofianuddin
}

\begin{abstract}
ABSTRAK : Kecerdasan emosional adalah kemampuan memotifasi diri sendiri, mengatasi frustasi, mengontrol desakan hati (mood), berempati serta kemampuan bekerja sama. Siswa mempunyai perasaan yang lebih positip tentang diri sendiri, sekolah dan keluarga. Individu mampu memahami penyebab perasaan yang timbul, mengenali perbedaan perasaan dengan tindakan. Prestasi belajar adalah hasil yang dicapai individu dalam penguasaan pengetahuan dan ketrampilan yang dikembangkan dalam pelajaran, lazimnya ditunjukkan dengan tes angka nilai yang diberikan oleh guru. Prestasi belajar merupakan bukti keberhasilan yang telah dicapai individu. Maka prestasi belajar adalah hasil maksimum yang dicapai seseorang tingkat prestasi belajar siswa kelas VIII SMP Negeri 1 Grati. Jenis penelitian ini adalah kuantitatif. Populasi penelitian adalah seluruh siswa kelas VIII SMP Negeril Grati sebanyak 282. Sedangkan pengambilan sampel menggunakan teknik Purposive samping sebanyak 142 responden. Teknik pengumpulan data kecerdasan emosional menggunakan sklala kecerdasan emosional dan pengumpulan data prestasi belajar siswa diperoleh dari dokumentasi berupa nilai rata-rata semester genap 2012/2013. Analisa data menggunakan Rank Sperman. Berdasarkan hasil analisis data dari skala kecerdasan emosional diketahui gambaran kecerdasan emosional dari 142 responden, 39 responden memiliki tingkat kecerdasn emosional sangat tinggi atau sebanyak $27.46 \%, 80$ responden memiliki tingkat kecerdasan emosional tinggi atau sebanyak 56.34\%, sedangkan 21 responden memiliki tingkat kecerdasan emosional rendah atau sebanyak $14.47 \%$ dan 2 siswa memiliki tinkat kecerdasan emosional sangat rendah atau sebanyak $1.41 \%$. Dan hasil prestasi belajar yang diambil dari nilai ratarata siswa semester genap tahun ajaran 2012/2013 yang berjumlah 142 reponden, menunjukkan 25 siswa memiliki prestasi belajar yang sangat baik (17.61\%), 81 siswa memiliki prestasi belajar yang sangat baik (57.04\%), 36 siswa memiliki prestasi belajar yang kurang (25.35\%) dan tidak ada siswa yang memiliki prestasi belajar sangat kurang.
\end{abstract}

Kata Kunci : Kecerdasan Emosioal, Prestasi Belajar

Prestasi belajar merupakan suatu hal yang paling penting dala konsep diri seseorang. Prestasi dikatakan baik apabila mendapatkan nilai yang baik setelah evaluasi. Prestasi belajar yang tinggi membuat seseorang yang prestise sehingga keaadaan diri, citra diri meningkat dan mempengaruhi kepribadian. Dengan kata lain jika mendapatkan prestasi yang tinggi, siswa akan merasa dirinya menjadi lebih dari yang lain sehingga terjadi peningkatan terhadap keadaan dan citra diri siswa. Bahwa prestasi yang baik akan mendapatkan citra baik pula seperti siswa berprestasi dan kecerdasan emosionalnya.
Setiap anak yang dilahirkan, telah membawa karakter dan sifatnya sendiri. Termasuk didalamnya juga telah membawa Kecerdasan Intelektual (IQ) dan Kecerdasan Emosional (EQ) dalam dirinya. Semua itu akan sangat mempengaruhi kepribadian, bahkan mungkin kegagalan atau kesuksesan. Anak-anak sekarang cenderung mulai banyak mengalami kesulitan emosional seperti mudah merasa kesepian dan pemurung, mudah cemas, mudah bertindak agresif, serta kurang menghargai sopan santun.

Kenyataan IQ yang tinggi bukan merupakan satu-satunya jaminan kesuksesan seorang anak dimasa depan. Ada factor lain 
yang saat ini cukup populer yaitu kecerdasasan ini karena banyak dijumpai anak-anak yang cerdas disekolah, begitu cemerlang prestasi akademiknya, namun tidak dapat mengelola emosinya seperti mudah marah, mudah putus asa atau angkuh dan sombong. Sehingga prestasi seperti yang telah diraih atau didapat tidak akan banyak bermanfaat bagi dirinya. Ada siswa yang mempunyai inteligensi tinggi tetapi memperoleh prestasi belajar yang relative rendah, namunada siswa yang kemampuan intelegensinya relative rendah, dapat meraih prestasi belajar yang relative tinggi. Itu sebabnya taraf inteligensi bukan merupakan satu-satunya factor yang menentukan keberhasilan seseorang, karena ada factor lain yang mempengaruhi. Menurut Goleman (2005 : 44), inteletual (IQ) hanya menyumbang $20 \%$ bagi kesuksesan, sedangkan $80 \%$ adalah sumbangan factor kekuatan - keuatan lain, diantaranya adalah kecerdasan emosional atau Emosional Quotient (EQ) yakni kemampuan memotifasi diri sendiri, mengatasi frustasi, mengontrol deakan hati, mengatur suasana hati (mood), berempati serta kemampuan bekerja sama.

Tanpa adanya konsentrasi yang baik dari individu dalam beraktivitas, maka mimpi bagi seseorang untuk dapat bekerja secara produktif, Konsentrasi individu dalam beraktivitas sangat dipengaruhi oleh kemampuan potensi atau kecerasan emosional individu yang bersangkutan. Pada umumnya individu yang mampu bekerja dengan penuh konsentrasi adalah individu yang memiliki tingkat intellegensia norml dengan tingkat kecerdasan emosional yang baik (tidak merasa bersalah yang berlebihan, tidak mudah marah, tidak dengki, tidak benci, tidak iri hati, tidak dendam, tidak sombong, tidak minder, tidak cemas, memiliki pandangan dan pedoman hidup yang jelas brdasarkan agamanya).

Dalam proses belajar siswa, kedua inteligensi itu sangat diperlukan. IQtidak dapat berfungsi dengan baik tanpa partisipasi penghayatan emosional terhadap mata pelajaran yang disampaikan disekolah. Namun biasanya kedua inteligensi itu saling melengkapi. Keseimbangan antara IQ dan an an $E Q$ merupakan kunci keberhasilan belajar siswa disekolah (Golemen, 2002 : 497).
Pendidkan disekolah bukan hanya perlu mengembangkan rational intelligence yaitu model pemahaman yang lazimnya dipahami siswa saja, melainkan juga perlu mengembangkan emosional intelligence siswa.

Dengan kecerdasan emosional, individu mampu mengetahui dan menanggapi perasaan-perasaan mereka sendiri dengan baik dan mampu membaca serta menghadapi perasaan-perasaan orang lain dengan efektif. Siswa dengan keterampilan emosional yang berkembang baik, siswa mampu menghadapi masalah yang terjadi dalam kehidupan dan memiliki motivasi dalam mencapai tujuan yang diinginkan, dan dapat mengontrol emosi didalam dirinya sendiri. Siswa yang hanya memiliki kecerdasan akademis tinggi, mereka cenderung memiliki rasa gelisah yang beralasan, terlalu krisis, rewel, cenderung menarik diri, terkesan dingin dan cenderung sulit mengekspresikan kekesalan dan kemarahannya secara tepat. Bila didukung dengan rendahnya taraf kecerdasan emosionalnya, maka orang-orang seperti ini sering menjadi sumber masalah. Karena sifatsifat diatas, bila sesoang memiliki $I Q$ tinggi namun tarah kecerdasan emosionalnya rendah maka cenderung akan terlihat sebagai orang yang keras kepala, sulit bergaul, mudah frustasi, tidak mudah percaya kepada orang lain, tidak peka dengan kondisi lingkungan dan cenderung putus asa bila mengalami stress. Kondisi sebaliknya, dialami oleh orangorang yang memiliki taraf $I Q$ rata-rata namun memiliki kecerdasan emosional yang tinggi.

SMP Negeri 1 Grati merupakan sekolah yang faforit, pada umumnya siswasiswi yang sekolah di SMP tersebut memiliki prestasi belajar baik dan Intelligence Questions (IQ) Tinggi, siswa-siswi yang masuk kesekolah tersebut haus mengikutibeberapa tes dan salah satu yang dilakukan yaitu tes tingkat kecerdasan intelektual Questions (IQ) serta harus memiliki NEM tinggi. Namun dalam pengalamannya tidak semua siswa berprestasi tinggi, hal ini dimungkinkan ada factor lain. Seperti yang dikemukakan oleh (Goleman, 2002 : 512) bahwa kecerdassan emosional (EQ) lebih berpengaruh dari pada kecerdasan intelektual (IQ) maka dalam penyusunan skripsi ini 
peneliti tertarik untuk meneliti " Hubungan antara Kecerdasan Emosional dengan Prestasi Belajar pada Siswa Kelas VIII SMP Negeri 1 Grati “.

\section{Tujuan Peneliti}

1. Tingkat kecerdasan emosional siswa kelas VIII SMP Negeri 1 Grati

2. Tingkat prestasi belajar siswa kelas VIII SMP Negeri 1 Grati

3. Hubungan kecerdasan emosional dengan prestasi belajar siswa kelas VIII SMP Negeri 1 Grati

\section{Batasan Masalah}

Berdasarkan masalah diatas, peneliti hanya membatasi permasalahan yaitu " Hubungan antara Kecerdasan Emosional dengan Prestasi Belajar pada siswa Kelas VIII SMP Negeri 1 Grati”.

\section{Manfaat Peneliti}

1. Dari segi teoritas, penelitian ini diharapkan dapat memberikan sumbangan bagiguru bimbingan dan konseling dan memperkaya hasil penelitian yang telah ada dan dapat memberikan gambaran mengenai hubungan kecerdasan emosional dengan prestasi belajar.

2. Dari segi prakti, penelitian ini diharapkan dapat membantu memberikan informasi khususnya kepada para orang tua, konselor sekolah dan guru dalam upaya membeimbing dan memotivasi siswa remaja untuk menggali kecerdasan emosional yang dimilikinya.

3. Peneliti, diharapkan peneliti ini dapat memperlancar proses pengembangan ilmu yang selama ini penulis dapatkan serta dapat memperlancar pencapaian gelar Sarjana Pendidikan (S1).

\section{KAJIAN PUSTAKA}

Menurut Wingkel (1997 : 168) bahwa proses belajar yang dialamai oleh siswa menghasilkan perubahan - perubahan dalam bidang pengetahuan dan pemahaman, dalam bidang nilai, sikap dan keterampilan. Adanya perubahan tersebut dalam prestasi belajar yang dihasilkan oleh siswa terhadap pertanyaan, persoalan atau tugas yang diberikan oleh guru. Melalui prestasi belajar siswa dapat mengetahui kemajuan - kemajuan yang telah dicapainya dalam belajar. Prestasi belajar yang dimaksud dalam penelitian ini adalah merata hasil belajar yang berupa nilai rata - rata siswa dari kegiatan pembelajaran di SMP Negeri 1 Grati selama waktu tertentu yang dilaporkan dalam raport dalam semester I dan II.

\section{Unsur - unsur Prestasi Belajar}

\section{Beberapa unsur - unsur prestasi belajar antara lain :}

a. Informasi Verbal

Pengetahuan yang mengandaikan kemapuan untuk menuangkan pengetahuan itu dalam bentuk bahasa, sehingga dapat dikomunikasikan kepada orang lain.

b. Keterampilan Intelektual

Persep, konsep, kaidah dan prinsip, yang masing - masing mengandaikan suatu kemampuan untuk mengendalikan diskriminasi antara obyek itu.

c. Keterampilan Motorik

Kemampuan untuk merangkaikan sejumlah gerak - gerik jasmani, sampai menjadi suatu keseluruhan yang dilakukan dengan gencar dan luwes, tanpa perlu memikirkan lagi secara mendetail apa yang dilakukan dan mengapa dilakukan.

d. Sikap

Memperoleh kecenderungan untuk menerima atau menolak suatu obyek, berdasarkan penilaian terhadap obyek itu sebagai hal yang berguna atau berharga (sikap posisi) atau tidak berharga atau berguna (sikap negative)

e. Siasat Kognitif

Suatu kemahiran tersendiri, siswa yang memiliki kemahiran ini mampu kognitif yang berlangsung dalam dirinya perhatian, bagaimana dia belajar, bagaimana dia menggali dari ingatan, bagaimana dia menggunakan pengetahuan yang 
dimilikinya, bagaimana dia berfikir dengan menggunakan konsep kaidah dan pengetahuan yang dimilikinya, khususnya bila mengahdapi problem atau masalah.

\section{Kecerdasan Emosional}

Keterampialan EQ bukanlah lawan keterampilan kognitif, namun keduanya berinteraksi secara dinamis baik pada tingkatan konseptual maupun didunia nyata. Selain itu, EQ tidak begitu dipengaruhi oleh factor keturunan . Kecerdasan emosional menurut pemilikan perasaan untuk belajar mengakui, menghargai perasaan pada diri dan orang lain serta menanggapinya dengan tepat, menerpakan secara efektif energy emosi dalam kehidupan sehari - hari. Kecerdasan emosional juga merupakan kemampun untuk menggunakan emosi secara efektif, untuk mencapai tujuan, untuk membangun produktivitas dan meraih keberhasilan (Goleman, 2005).

\section{Aspek - aspek Kecerdasan Emosional}

a. Mengenali Emosi Diri.

Mengenali emosi diri sendiri merupakan suatukemampuan untuk mengenali perasaan sewaktu perasaan itu terjadi. Kemampuanini merupakandasardari kecedarsan emosi, para ahli psikologi menyebutkan kesadaran diri sebagai metamood, yakni kesadaran seseorangakanemosinya sendiri. Menurut mayer (Golemen, 2002 : 64) kesadarandiri adalah waspadaterhadap suasana hati maupun pikiran tentang suasana hati, bila kurang waspada maka individu menjadi mudah larut dalam aliran emosi dan dikuasai oleh emosi. Kesadaran diri memang belum menjadi penguasaanemosi, namun merupakan salahsatu prasyarat penting menjadi penguasaan emosi, namun merupakan salah satu prasaratpenting unuk mengendalikan emosi sehingga individu mudah menguasai emosi.

b. Mengeloala Emosi.

Mengelola emosi merupakan kemampuan individu dalam menangani perasaan agar dapat terungkap dengan tepat atau selaras, sehinggatercapai keseimbangan dalam diri individu. Menjaga agar emosi yang merisaukan tetap terkendali merupakan kunci menuju kesejahteraan emosi. Emosi berlebihan, yang meningkat dengan intensitas terlampau lama akan mengoyak kestabilan kita(Goleman, 2002 : 77). Kemampuan ini menacakup kemampuan untuk menghibur diri sendiri, melepaskan kecemasan, kemurungan atau ketersinggungan dan akibat-akibat yang ditimbulkannya sertakemampuan untuk bangkit dari perasaan-perasaan yang menekan.

c. Memotivasi Diri Sendiri.

Prestasi harus dilalui dengan dimilikinya motivasi dalam diri individu, yang berarti memiliki ketekunan untuk menahan diri terhadap kepuasan dan mengendalikan dorongan hati, serta mempunyai perasaan motivasi yang positif, yaitu antusianisme, gairah. Optimis dan keyakinan diri.

d. Mengenali Emosi Orang Lain.

Kemampuan untuk mengenali emosi orang lain disebut juga empati. Menurut Goleman (2002 : 57) kemampuan seseorang untuk mengenali orang lain atau peduli, menunjukan kemapuan empati seseorang. Individu yang memiliki kemapuan emosi lebih mampu menangkap sinyal-sinyal social yan tersembunyi yang menginsyaratkan apa-apa yang dibutuhkan orang lain sehingga ia lebih mampu menerima sudut pandang orang lain, peka terhadap perasaan orang lain dan lebih mampu untuk mendengarkan orang lain.

Rosenthal dalam penelitiannya menunjukan bahwa orang-orang yang mampu membawa perasan dan isyarat non verbal lebih mampu menyesuaikan diri secara emosional, lebih popler, lebih mudah bergaul, dan lebih peka (Goleman, 2002 : 136). Nowichi, ahli psikologi menjelaskan bahwa anak-anak yang tidak mampu membawa atau mengungkapkan emosi dengan baik akan terus menerus merasa frustasi (Goleman, 2002 : 172). Seseorang yang mampu membaca emosi orang lain juga memiliki kesadaran diri yang tinggi, Semakin mapu terbuka pada emosinya sendiri, mampu mengenal dan mengakui emosinya sendiri, maka orang tersebut mempunyai kemampuan untuk membaca perasan orang lain.

e. Membina Hubungan. 
Kemapuan dalam membina hubungan merupakan sutuketrampi yang menunjang popularitas, kepemimpinan dan keberhasilan antar pribadi (Goleman, 2002 : 59). Keterampilan dalam berkomonikasi merupakan kemampuan dasar dalam keberhasilan membina hubungan. Individu sulit untuk mendapatkan apa yang diinginkan dan sulit juga memahami keinginan serta kemauan orang lain. Orangorang yang hebat dalam keterampilan membina hubungan ini akan sukses dalam bidang apapun. Orang berhasil dalam pergaulan karena mampu berkomunikasi dengan lancer pada orang lain. Orangorang ini popular dalam lingukungannya dan menjadi teman yang menyenangkan karena kemampuannya berkomunikasi (Goleman, 2002 : 59). Ramah tamah, baik hati, hormat dan disukai orang lain dapat dijadikan petunjuk positif bagaimana siswa mampu membina hubungan dengan orang lain. Sejauhmana kepribadian siswa berkembang dilihat dari banyaknya hubungan interpersonal yang dilakukan.

\section{Hubungan Antara Kecerdasan Emosional dengan Prestasi Belajar pada Siswa SMP}

Kecerdasan Intelektual (IQ)dan Kecerdasan Emosional (EQ)dalamdiri siswa akan sangat mempengaruhi kepribadian, bahwa mungkit dalam kegagalan dan kesuksesannya dimasa depan, Dalam proses belajar siswa, kedua intelegensi itu sangatlah dibutuhkanoleh siswa. $I Q$ tidak dapat berfungsi dengan baik tanpa partisipasi penghayatan emosional terhadap mata pelajaran yang disampaikan di sekolah, dan $E Q$ berfungsi sebagai moivasi diri sendiri dalam proses belajar, mengatasi frustasi, mengontrol desakan hati, dan mengatur suasana hati (mood) dalam proses belajar siswa. Antara $I Q$ dan $E Q$ harus seimbang dalam meraih keberhasilan prestasi belajar siswa di sekolah. Contoh yang dapat dilihat dari siswa yakni Zamrotul kelas VIII C, pada saat proses pembelajaran dan ulangan nilai total yang diperoleh nilai rendah dengantotal 1066. Hal ini dikarenakan banyak siswa yang memiliki kecerdasan intelektual (IQ) tinggi namun kecerdasn emosional (EQ) rendah, dengan tidak seimbangnya antara IQ dan EQ membuat kegagalan dalam berprestasi. Prestasi belajar lebih ditentukan oleh kecerdasan (IQ), maka semakin tinggi IQ, semakin tinggi juga prestasi belajar siswa. Hal ini dapat dilihat dari perolehan hasil-hasil ulangan harian, ujian, dan nilai-nilai dalam raport, menjadi juara-juara kelas atau juara sekolah. Namun demikian, kenyataan bahwa kecerdasan emosional sangatlah berpengaruh terhadap usaha belajar siswa yang pada akhirnya ingin mencapai prestasi tertentu, siswa tidak akan mudah menyerah dengan kesulitan yang dihadapinya dalam belajar. Siswa akan memotivasi diri sendiri untk berprestasi dalam belajarnya.

\section{METODE PENELITIAN}

Penelitian ini menggunakan metode kuantitatif. Penelitian kuantitatif adalah penelitian yang berwujud angka-angka mulai dari pengumpulan data, penafsiran data, serta penampilan hasilnya (Arikunto, 2006 : 172). Sesuai dengan permasalahan dan tujuan penelitian ini maka rancangan penelitian yang sesuai adalah penelitian deskripsi koreksionel. Penelitian deskriptif dimaksudkan untuk eksplorasi dan klarifikasi mengenai suatu fenomena alami kenyataan social dengan jalan mendiskripsikan sejumlah variable yang berkenan dengan masalah dan unit yang diteliti (Faisal, 2001). Metode korelasional untuk menggunakan hubungan korelatif antar variable, dan mengacu pada kecenderungan bahwa variasi suatu variabel diikuti oleh variabel yang lain (Purwanto, 2008). Penelitian ini dilakukan untuk mengetahi hubungan antara kecerdasan emosional dengan prestasi belajar pada siswa. Sebagai populasi pada penelitian ini adalah siswa kelas VIII SMP belajar pada siswa. Sebagai populasi pada penelitian ini adalah siswa kelas VIII SMP Negeri Grati Berjumlah 282 siswa. Dalam penelitian ini diambil sampel sebanyak $50 \%$ dari populasi yang ada dengan cara konselor menunjuk siswa yang duduk di barisan sebelah kanan akan dijadikan sampel dalam penelitian akan membantu peneliti dalam pengambilan data. 


\section{HASIL PENELITIAN DAN PEMBAHASAN}

Berdasarkan analisa siswa yang memiliki prestasi belajar tinggi dapat diartikan siswa memiliki intelegensi yang tinggi, menunjukkan sikap positif, motivasi tinggi, kecerdasan emosional yang tinggi, factor lingkungan social dan lingkungan non sosialnya yang mendukung. Sedangkan siswa yang memiliki presatasi belajar rendah berarti siswa memiliki intelegensi yang rendah, sikap positif yang kurang, motivasi rendah, kecerdasan emosional rendah dan kurangnya dukungan dari lingkungan social dan lingkungan nonsosial.

Berdasarkan hasil analisis data dari skala kecerdasan emosional diketahui gambaran kecerdasan emosional dari 142 responden, 39 responden memiliki tingkat kecerdasn emosional sangat tinggi atau sebanyak $27.46 \%, 80$ responden memiliki tingkat kecerdasan emosional tinggi atau sebanyak $56.34 \%$, sedangkan 21 responden memiliki tingkat kecerdasan emosional rendah atau sebanyak $14.47 \%$ dan 2 siswa memiliki tinkat kecerdasan emosional sangat rendah atau sebanyak $1.41 \%$.

Dan hasil prestasi belajar yang diambil dari nilai rata-rata siswa semester genap tahun ajaran 2012/2013 yang berjumlah 142 reponden, menunjukkan 25 siswa memiliki prestasi belajar yang sangat baik $(17.61 \%), 81$ siswa memiliki prestasi belajar yang sangat baik $(57.04 \%), 36$ siswa memiliki prestasi belajar yang kurang $(25.35 \%)$ dan tidak ada siswa yang memiliki prestasi belajar sangat kurang.

\section{PENUTUP}

\section{Kesimpulan}

Dari hasil peneliti dan pembahasan, maka simpulan dalam penelitian ini adalah sebagai berikut :

1. Dari hasil analisis data kecerdasan emosional dari 142 siswa kelas VIII kelas SMP Negeri 1 Grati sebagian besar memiliki tingkat kecedasan emosional tinggi $(56,34 \%)$, kurang dari separuh siswa memiliki tingkat kecerdasan emosional sangat tinggi $(27,46 \%)$ sebagian kecil siswa memiliki tingkat kecerdasan emosional rendah $(14,79 \%)$ dan siswa memiliki tingkat kecerdasan emosional sangat rendah $(1,41 \%)$.

2. Berdasarkan hasil pengambilan data prestasi belajar dari 142 siswa kelas VIII SMP Negeri 1 Grati menunjukan bahwa sebagian besar memiliki prestasi belajar tinggi (57,04\%), kurang dari separuh memiliki prestasi belajar yang rendah $(25,35 \%)$, sebagian kecil memilki prestasi belajar sangat tinggi(17,79\%), dan tidak ada siswa yang memiliki prestasi belajar sangat rendah $(0 \%)$.

3. Berdasarkan hasil anlisis korelasi antara kecerdasan emosional siswa dengan prestasi belajar siswa kelas VIII SMP Negeri 1 Grati menunjukan $\mathrm{r}_{\text {hitung }}=0,510 \mathrm{p}$ $=0,000$ yang berarti bahwa hipotesis yang diajukan diterima, yaitu terdapat hubungan positif yang signifikan antara kedua variable. Dari hasil analisis tersebut maka dapat dinyatakan bahwa semakin tinggi kecerdasanemosional siswa maka akan semakin tinggi pula prestasi belajar siswa.

\section{SARAN}

1. Segi teoritis

Pengembangan kecerdasan emosional yang baik perlu didukung dengan adanya belajar yang positif dan kondisif melalui dari sumber-sumber belajar bagi siswa, agar siswa mencapai prestasi belajar terbaik.

2. Segi praktis

\section{a. Bagi sekolah}

Kepala sekolah menciptakan lingkungan kerja dan yang meningkatkan semua prodi dikolah dalam mengembangkan kecerdasan emosional.

b. Bagi guru

1. Supaya pencapaian hasil belajar optimal, butuh pengembangan suasana belajar yang mengkaitkan perkembangan emosional.

2. Guru sebagai model hendaknya menampilkan kecerdasan emosional secara optimal. 
3. Bagi peneliti

Bagi peneliti agar lebih detail dalam menggali dan meningkatkan kecerdasan emosional siswa yang kaitannya dengan prestasi belajar siswa. Diharapkan lebih luas dalam peneliti lain mengambil populasi dan sampel yang lebih banyak, dapat mengembangkan teori dan instrument serta dikaitkan dengan factor lainnya.

\section{DAFTAR PUSTAKA}

Ahmadi, Abu \& Widodo Supriono. 2008. Psikologi Belajar Edisi Revisi. Bandung : Rineka Cipta.

Arikunto, Suharsini. 2006. Prosedur Penelitian. Jakarta : Rineka Cipta.

Departemen Pendidikan dan Kebudayaan. 1997. Kamus Besar Bahasa Indonesia. Jakarta : Balai Pustaka.

Djamarah, Saiful Bahri. 1994. Prestasi Belajar dan Kompetensi Guru .Surabaya : Usaha Nasional.

Fakholiqs, Fifi. 2010. Ciri-ciri Siswa Berprestasi. Jakarta :Psychological Journal.

Goleman, D. 2002. Emotional Intelelligence. Terjemah Rahayu lestari. Jakarta : PT Gramedia Pustaka Utama.

Goleman, D. 2005. Kiat - kiat Membesarkan Anak yang memiliki Kecerdasan Emosional (terjemahan). Jakarta : PT Gramedia Pustaka Utama.

Ibda, Fatimah. 2000. Emotional Intellegence dalam Dunia pendidikan. Banda Ace : Fakultas Tarbiyah, IAIN Ar-Raniry, Jurnal Didaktika, Vol.2

Perkembangan aspek fisik, motoric, kognitif, bahasa moal, sosiao, emosi dan agama pada anak.

http://google.wednet.Diy4h's/World/ste ntr.html
Lindawati, Elizabeth. 2011. Program Studi Bimbingan dan Konseling Angkatan 2009 Universitas Kanjuruhan Malang. Hubungan antara Kecerdasan Emosional dan Self-Regulerad Learning dengan prestasi Belajar mahasiswa. Skripsi. Malang : Program Studi Bimbingan dan Konseling Universitas kanjuruhan Malang.

Purwanto.2008.Metodologi Penelitian Kuantitatif untuk Psikologi dan Pendidikan.Yogyakarta:Pustaka Pelajar.

Slameto. 2010. Belajar dan Faktor-faktor yang mempengaruhi Edisi Revisi. Bandung : Rineka Cipta.

Sobur, Alex. 2013. Psikologi Umum.Bandung : Pustaka Setia.

Sulastri. 2010. Hubungan antara Kebiasaan Belajar dengan Belajar Siswa Kelas VIII SMP Negeri 1 Wlingi. Skripsi. Malang : Program Studi Bimbingan dan Konseling Universitas Kanjuruhan Malang.

Syah, Muhibbin. 2010. Psikologi Pendidikan Cetakan ke-16. Bandung : Rosdakarya.

Winkel, WS. 1997. Psikologi Pendidikan dan Evaluasi Belajar. Jakarta : Gramedia

Wahyuningsih. 2004. Hubungan Antara Kecerdasan Emosional dengan Prestasi Belajar pada siswa kelas II SMU Lab School Jakarta Timur.

Yusuf, Syamsu. 2004. Psikologi Perkembangan Anak dan Remaja. Bandung : Rosda Karya. 